\title{
Development of Nonbacterial Thrombotic Endocarditis While on Systemic Anticoagulation in Pancreatic Cancer: A Case Report
}

Jiasheng Wang ${ }^{1}$, Natasha Monga ${ }^{2}$, Prashanth Mopala ${ }^{3}$, Muhammad Husnain ${ }^{4}$

1. Department of Internal Medicine, MetroHealth Medical Center, Cleveland, USA 2. Department of Radiology, MetroHealth Medical Center, Cleveland, USA 3. Department of Cardiology, MetroHealth Medical Center, Cleveland, USA 4. Department of Medicine, MetroHealth Medical Center, Cleveland, USA

Corresponding author: Muhammad Husnain, mhusnain@metrohealth.org

\begin{abstract}
Nonbacterial thromboembolic endocarditis (NBTE), or marantic endocarditis, is a rare complication associated with advanced cancer. Enoxaparin or unfractionated heparin is considered the standard treatment for NBTE. In this case report, we describe a 59-year-old female with metastatic pancreatic cancer who presented with embolic stroke and was found to have new NBTE of the mitral valve while she was receiving the therapeutic dose of enoxaparin. Of note, her recent echocardiogram one week ago was negative for mitral valve vegetations. Our case emphasized that for patients with advanced cancer presenting with stroke, the diagnosis of NBTE should be entertained even for those on systemic anticoagulation.
\end{abstract}

Categories: Cardiology, Neurology, Oncology

Keywords: nonbacterial thrombotic endocarditis, pancreatic cancer, anticoagulation

\section{Introduction}

Marantic or nonbacterial thromboembolic endocarditis (NBTE) is a rare event seen in patients with advanced malignancy [1]. The vegetations of NBTE are commonly noninflammatory platelet-fibrin deposits usually located on aortic and mitral valves. The treatment for NBTE involves systemic anticoagulation with a therapeutic dose of low molecular weight heparin (LMWH) or unfractionated heparin (UFH). The development of new NBTE and embolic stroke while on LMWH has not been reported.

\section{Case Presentation}

A 59-year-old female was admitted to the hospital for shortness of breath and found to have bilateral pulmonary emboli diagnosed by computed tomography pulmonary angiogram. Incidentally noted were numerous ill-defined hypodense hepatic lesions with subsequent percutaneous liver biopsy consistent with metastatic pancreatic adenocarcinoma. A transthoracic echocardiogram (TTE) was also performed at that time (Figure 1), which showed unremarkable valves (Figure 1A). The patient was discharged home on the therapeutic dose of enoxaparin $(1 \mathrm{mg} / \mathrm{kg}$ administered subcutaneously twice a day). Review ended 10/15/2020 Published 10/15/2020

\section{() Copyright 2020}

Wang et al. This is an open access article distributed under the terms of the Creative Commons Attribution License CC-BY 4.0., which permits unrestricted use, distribution, and reproduction in any medium, provided the original author and source are credited.

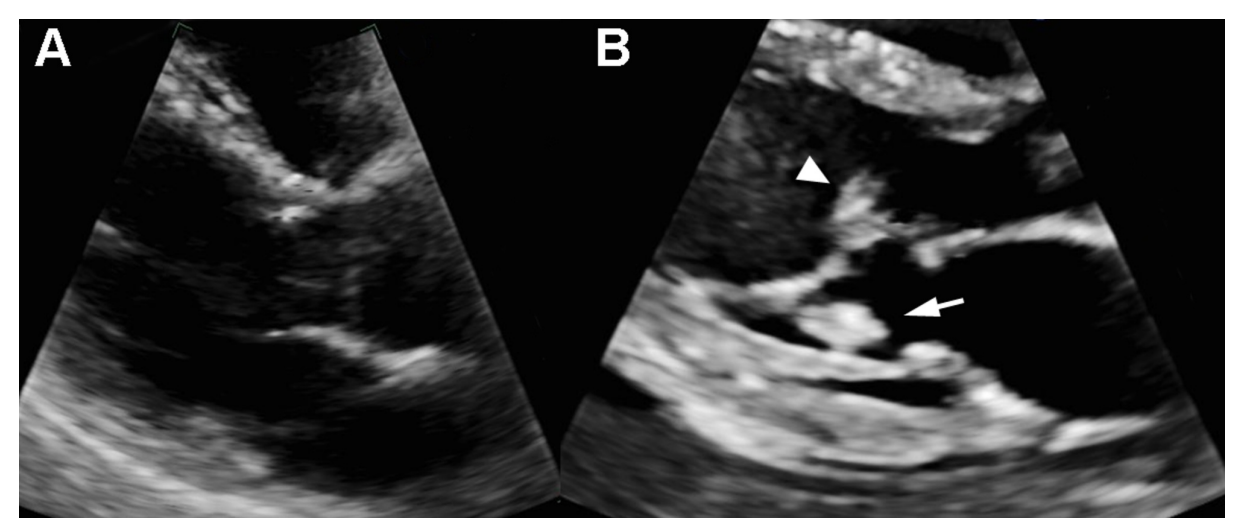

FIGURE 1: Echocardiogram two weeks prior and on the day of admission

Two weeks prior to the current presentation, no obvious vegetations were identified on echocardiogram (A). A repeat echocardiogram at this admission (B) demonstrated two vegetations attached to the anterior leaflet chordae (arrowhead) and the posterior leaflet chordae (arrow) of the mitral valve, respectively. 


\section{Cureus}

Two weeks later, the patient presented from the oncology clinic with acute confusion for one day. Of note, no treatment for pancreatic cancer has been started. Laboratory tests showed normal renal function, normal fibrinogen level, and normal platelet counts; activated partial thromboplastin time was normal, but prothrombin time was slightly prolonged (15 seconds, normal 9.7 to 12.9 seconds). Two sets of blood cultures were obtained, which returned negative. Unenhanced magnetic resonance imaging of the brain demonstrated numerous foci of restricted diffusion bilaterally, consistent with microemboli (Figure 2).

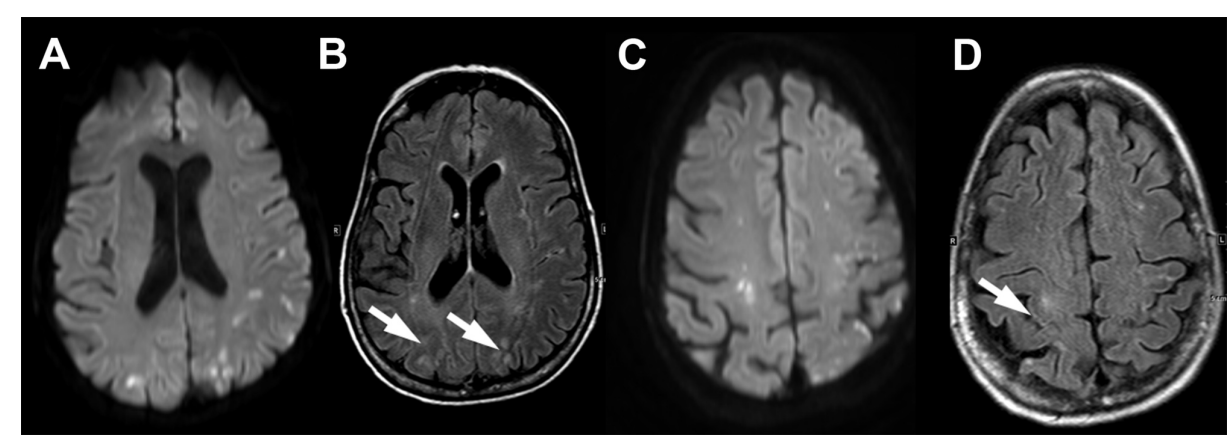

\section{FIGURE 2: Brain MRI on the day of admission}

Diffusion-weighted sequences ( $A$ and $C$ ) demonstrate numerous cortical and subcortical foci of restricted diffusion in frontal and parietal lobes. On the FLAIR sequences (arrows B and D), these foci are only mildly hyperintense, consistent with acute embolic infarcts involving the anterior circulation.

MRI: magnetic resonance imaging; FLAIR: fluid-attenuated inversion recovery

A limited TTE showed two new masses, measuring $1.2 \times 0.7 \mathrm{~cm}$ and $1.1 \times 0.9 \mathrm{~cm}$, attached to the mitral valve anterior leaflet chordae and the posterior leaflet chordae, respectively (Figure 1B). Of note, a family member reported that the patient had been administering enoxaparin consistently. Enoxaparin was continued in the hospital. However, her mental status continued to decline, and she became comatose in 24 hours. The family elected comfort care, and the patient passed away after four days.

\section{Discussion}

In this case report, we described a patient with recently diagnosed metastatic pancreatic cancer who developed NBTE that led to the formation of cerebral microemboli while on the therapeutic dose of LMWH for pulmonary embolism. The mechanisms of ischemic stroke in cancer patients are often undetermined. However, NBTE seems to be a leading cause as evidenced by an autopsy study [2]. Diagnosing NBTE with echocardiogram is often difficult due to the small sizes of vegetations. Nonetheless, they are extremely thrombogenic and can dislodge easily due to loose attachment to undamaged cardiac valves. Moreover, several features in our patient, such as mitral valve involvement, a size larger than $10 \mathrm{~mm}$, and more than one vegetations, are associated with a higher risk of embolism [3]. LMWH or UFH is the standard treatment for NBTE [4]. The evidence of anticoagulation comes from observational studies, where improved neurological symptoms were observed when anticoagulation was initiated [5]. For patients with late-stage pancreatic cancer, a new occurrence of NBTE while on LWMH has not been reported. However, the literature review showed recurrent embolic stroke while on systemic anticoagulation was common in this population (Table 1). 


\section{Cureus}

\begin{tabular}{|c|c|c|c|c|c|c|c|}
\hline Study & $\begin{array}{l}\text { Patient age } \\
\text { (years), sex }\end{array}$ & $\begin{array}{l}\text { Cancer } \\
\text { stage }\end{array}$ & $\begin{array}{l}\text { Location of } \\
\text { NBTE }\end{array}$ & $\begin{array}{l}\text { ATE } \\
\text { presentation }\end{array}$ & $\begin{array}{l}\text { Size of } \\
\text { NBTE }\end{array}$ & Treatment & $\begin{array}{l}\text { Neurological } \\
\text { outcome }\end{array}$ \\
\hline \multirow{2}{*}{$\begin{array}{l}\text { Jameson et al. } \\
{[6]}\end{array}$} & $64, \mathrm{M}$ & IV & $\begin{array}{l}\text { Anterior leaflet of } \\
\text { MV }\end{array}$ & AIS & N/A & Warfarin & Recurrent AIS \\
\hline & $61, M$ & IV & $\begin{array}{l}\text { Across intra- } \\
\text { atrial septum }\end{array}$ & AIS & N/A & Warfarin & Recurrent TIA \\
\hline Sia et al. [7] & $54, \mathrm{~F}$ & $\begin{array}{l}\text { Locally } \\
\text { advanced }\end{array}$ & AV & $\begin{array}{l}\text { AIS, MI, limb } \\
\text { ischemia }\end{array}$ & $7 \times 4 \mathrm{~mm}$ & None & Died \\
\hline $\begin{array}{l}\text { Smeglin et al. } \\
\text { [8] }\end{array}$ & $43, F$ & IV & AV & Limb emboli & N/A & UFH & N/A \\
\hline $\begin{array}{l}\text { Piovanelli et } \\
\text { al. [9] }\end{array}$ & $48, F$ & N/A & AV & AIS & $\mathrm{N} / \mathrm{A}$ & UFH & Recurrent AIS \\
\hline $\begin{array}{l}\text { Starobinska et } \\
\text { al. [10] }\end{array}$ & $66, \mathrm{M}$ & $\begin{array}{l}\text { Locally } \\
\text { advanced }\end{array}$ & $\begin{array}{l}\text { Posterior leaflet } \\
\text { MV }\end{array}$ & AIS & $11 \times 7 \mathrm{~mm}$ & $\begin{array}{l}\text { Systemic } \\
\text { anticoagulation }\end{array}$ & Stable \\
\hline $\begin{array}{l}\text { Chen et al. } \\
\text { [11] }\end{array}$ & $81, F$ & IV & MV & AIS, MI & $\begin{array}{l}6 \times 8 \mathrm{~mm}, \\
5 \times 5 \mathrm{~mm}\end{array}$ & None & Died \\
\hline $\begin{array}{l}\text { Mantovani et } \\
\text { al. [12] }\end{array}$ & $65, F$ & N/A & $\mathrm{AV}, \mathrm{MV}$ & None & N/A & LWMH & N/A \\
\hline $\begin{array}{l}\text { Takeshita et } \\
\text { al. [13] }\end{array}$ & $65, F$ & IV & AV & AIS & N/A & UFH & Recurrent AIS \\
\hline
\end{tabular}

\section{TABLE 1: Literature review of nonbacterial thrombotic endocarditis in patients with pancreatic}

cancer

NBTE, nonbacterial thrombotic endocarditis. ATE, arterial thromboembolism. M, male. F, female. MV, mitral valve. AV, aortic valve. AIS, acute ischemic stroke. N/A, not available. TIA, transient ischemic attack. MI, myocardial infarction. UFH, unfractionated heparin. LWMH, low-molecularweight heparin.

Therefore, the occurrence of new NBTE in our patient likely reflects the hypercoagulability associated with pancreatic cancer. However, the development of antiphospholipid antibody or medication noncompliance could not be excluded. For patients with new NBTE while on anticoagulation, little evidence is available for alternative treatments. However, the use of direct oral anticoagulants (DOAC) should be cautioned, as Mantovani et al. [12] reported a patient who developed NBTE while on rivaroxaban, but vegetations disappeared after DOAC was switched to LWMH.

\section{Conclusions}

In conclusion, for patients with advanced cancer presenting with ischemic stroke, the diagnosis of NBTE should be entertained even for those on systemic anticoagulation.

\section{Additional Information}

\section{Disclosures}

Human subjects: Consent was obtained by all participants in this study. Conflicts of interest: In compliance with the ICMJE uniform disclosure form, all authors declare the following: Payment/services info: All authors have declared that no financial support was received from any organization for the submitted work. Financial relationships: All authors have declared that they have no financial relationships at present or within the previous three years with any organizations that might have an interest in the submitted work. Other relationships: All authors have declared that there are no other relationships or activities that could appear to have influenced the submitted work.

\section{References}

1. Mazokopakis EE, Syros PK, Starakis IK: Nonbacterial thrombotic endocarditis (marantic endocarditis) in cancer patients. Cardiovasc Hematol Disord Drug Targets. 2010, 10:84-86. 10.2174/187152910791292484

2. Graus F, Rogers LR, Posner JB: Cerebrovascular complications in patients with cancer . Medicine (Baltimore). 1985, 64:16-35. 10.1097/00005792-198501000-00002

3. Bayer AS, Bolger AF, Taubert KA, et al.: Diagnosis and management of infective endocarditis and its 
complications. Circulation. 1998, 98:2936-2948. 10.1161/01.cir.98.25.2936

4. Whitlock RP, Sun JC, Fremes SE, Rubens FD, Teoh KH: Antithrombotic and thrombolytic therapy for valvular disease. Antithrombotic therapy and prevention of thrombosis, 9th ed. American College of Chest Physicians Evidence-Based Clinical Practice Guidelines. Chest. 2012, 141:576-600. 10.1378/chest.11-2305

5. Rogers LR, Cho ES, Kempin S, Posner JB: Cerebral infarction from non-bacterial thrombotic endocarditis. Clinical and pathological study including the effects of anticoagulation. Am J Med. 1987, 83:746-756. 10.1016/0002-9343(87)90908-9

6. Jameson GS, Ramanathan RK, Borad MJ, Downhour M, Korn R, Von Hoff D: Marantic endocarditis associated with pancreatic cancer: a case series. Case Rep Gastroenterol. 2009, 3:67-71. 10.1159/000207195

7. Sia CH, Lim JS, Poh KK, Chin TM: A classical case of non-bacterial thrombotic endocarditis from pancreatic adenocarcinoma presenting as multiple strokes, myocardial infarction and acute limb ischaemia. Oxf Med Case Reports. 2016, 2016:084. 10.1093/omcr/omw084

8. Smeglin A, Ansari M, Skali H, Oo TH, Maysky M: Marantic endocarditis and disseminated intravascular coagulation with systemic emboli in presentation of pancreatic cancer. J Clin Oncol. 2008, 26:1383-1385. 10.1200/JCO.2007.12.9148

9. Piovanelli B, Rovetta R, Bonadei I, Vizzardi E, D'Aloia A, Metra M: Nonbacterial thrombotic endocarditis in pancreatic cancer. Monaldi Arch Chest Dis. 2013, 80:189-192. 10.4081/monaldi.2013.5236

10. Starobinska E, Robinson EA, Brucks E, Scott S: Marantic endocarditis: incidental infarcts leading to diagnosis of pancreatic cancer. BMJ Case Rep. 2018, 2018:bcr-2018-224529. 10.1136/bcr-2018-224529

11. Chen L, Li Y, Gebre W, Lin JH: Myocardial and cerebral infarction due to nonbacterial thrombotic endocarditis as an initial presentation of pancreatic adenocarcinoma. Arch Pathol Lab Med. 2004, 128:13071308.

12. Mantovani F, Navazio A, Barbieri A, Boriani G: A first described case of cancer-associated non-bacterial thrombotic endocarditis in the era of direct oral anticoagulants. Thromb Res. 2017, 149:45-47. 10.1016/j.thromres.2016.11.016

13. Takeshita S, Ogata T, Mera H, Tsugawa J, Aoki M, Takeshita M, Tsuboi Y: Multiple thrombi in the heart in trousseau syndrome caused by pancreatic carcinoma. J Stroke Cerebrovasc Dis. 2018, 27:75-77. 10.1016/j.jstrokecerebrovasdis.2017.12.005 